\title{
Media pembelajaran berbasis android untuk meningkatkan motivasi dan hasil belajar siswa
}

\author{
Rika Andriani', Asep Suratman² \\ 1. SMAN 15 Bandung, Jln Sarimanis No 1, Bandung \\ 2. SMAN 1 Cicalengka Kab Bandung, Jn. H. Darham No 42, Cicalengka, Kab Bandung \\ *andrianirika@sman15bdg.sch.id
}

Received: 23 Desember 2020 ; Accepted: o9 Juni 2021; Published: 30 Juni 2021

\begin{abstract}
Abstrak
Pembelajaran jarak jauh selama pandemi memberikan pengalaman belajar baru bagi siswa. Sumber belajar yang praktis dan ramah kuota sangat diperlukan bagi siswa. Peneliti membuat sebuah inovasi media pembelajaran berbasis android. Penelitian ini bertujuan untuk mengetahui pengaruh penggunaan media pembelajaran berbasis android yang dibuat oleh peneliti, terhadap motivasi dan hasil belajar siswa. Penelitian dilakukan pada siswa kelas XI SMAN 15 Bandung, menggunakan Pre-Experiment Design. Instrumen yang digunakan berupa angket dan soal tes. Hasil pengolahan data diperoleh kesimpulan bahwa penggunaan media pembelajaran berbasis android dapat meningkatkan motivasi dan hasil belajar siswa.
\end{abstract}

Kata kunci: Media pembelajaran, Android, Motivasi, Hasil belajar

\begin{abstract}
Distance learning during a pandemic provides a new learning experience for students. Practical and quota-friendly learning resources are indispensable for students. Researchers create an Android-based learning media innovation. This study aims to determine the effect of using android-based learning media made by researchers, on students' motivation and learning outcomes. The research was conducted on students of class XI SHS 15 Bandung, using Pre-Experiment Design. The instruments used are in the form of questionnaires and test questions. The results of data processing concluded that the use of android-based learning media can increase student motivation and learning outcomes.
\end{abstract}

Keywords: Learning media, Android, Motivation, Learning outcomes 


\section{PENDAHULUAN}

Pendidikan merupakan kegiatan yang dilakukan sepanjang hayat oleh setiap individu dengan tidak membedakan secara diskriminatif, sehingga pendidikan harus dapat mencakup semua kebutuhan peserta didiknya sesuai dengan karakteristik dari setiap individunya. Salah satu cara nya yaitu dengan cara memberdayakan seluruh komponen guna menyelenggarakan dan mengendalikan mutu pendidikan. (UU No. 20 Tahun 2003 Bab II Pasal 3). Guna mengendalikan mutu pendidikan, maka seorang pendidik harus dapat berinovasi dalam menyelenggarakannya, jika pembelajaran bersifat tatap muka, seorang pendidik harus dapat menciptakan suasana yang menarik sehingga peserta didik merasa tertarik pada saat mereka melakukan proses pendidikan. (Setiawan, Risky, dkk: 2019)

Tahun Pelajaran 2020-2021 bergulir di tengah masa pandemi. Hal ini mengharuskan kita melakukan Pembelajaran Jarak Jauh (PJJ). Hal ini menjadi tantangan baru baik untuk guru, siswa, maupun orang tua. Semua harus melakukan penyesuaian diri dengan tuntutan kurikulum dan kebiasaan baru. Salah satu hal terpenting dalam proses pembealajarn adalah sumber belajar (Lilawati, Jenny :2017).

Pada era digital ini, sebenaranya sumber belajar melimpah ruah di dunia maya. Asalkan siswa mau berselancar, dia akan dapat memperoleh apa saja informasi yang diinginkan, termasuk sumber belajar untuk mata pelajaran di sekolah. Beberapa sumber belajar dapat diperoleh dari website atau blog yang bias langsung dibaca. Ataupun dalam bentuk PDF dan Power Point (PPT) yang bisa diunduh oleh pengguna internet. Sumber belajar berupa PDF dan PPT juga sering kali dibagikan oleh guru melalui WhatsApps pada saat pembelajaran berlangsung (Sona Rahmada Yani, Menik Kurnia Siwi: 2020).

Guru menyadari, tidak semua siswa berinisiatif membeli buku paket. Dan tidak semua siswa mau berselancar mencari sumber belajar sendiri. Sehingga untuk memudahkan menyampaikan materi dan membekali siswa, guru membagikan file sumber belajar berupa PDF dan PPT.

File bentuk PDF dan PPT merupakan file yang umum bisa dibuka pada umumnya Handphone (HP) android yang dimiliki siswa. Siswa dapat dengan mudah membuka dan membacanya, karena saat di klik otomatif file terunduh. Namun ada kelemahan pemberian sumber belajar dalam bentuk file, jika kita ingin membuka kembali, sering kali kita kesulitan mencari file tersebut. Karena penyimpanan file di HP biasanya tidak serapih penyimpanan file di komputer/laptop. File yang tersimpan di WA biasanya sudah tertutup jauh oleh percakapanpercakapan lainnya, sedangkan mencari di File Manager HP juga seringkali kebingungan karena terlalu banyak file terunduh (Edi Ismanto, dkk : 2017).

Berlatar belakang kondisi seperti ini, saya memiliki ide untuk mengemas sumber belajar dalam bentuk yang lebih sederhana dan praktis bagi siswa. Karena HP sudah menjadi bagian tak terpisahkan dari kehidupan siswa, maka sumber belajar pun harus menjadi bagian tak terpisahkan dari keseharian siswa. Sehingga sumber belajar akan disematkan pada layar HP dalam bentuk aplikasi, selanjutnya kita sebut media pembelajaran berbasis android.

Diharapkan dengan adanya media pembelajaran berbasis android, memudahkan siswa dalam mengakses sumber belajar, dimanapun mereka berada, sepanjang dia membawa HP. Aplikasi ini juga dapat digunakan tanpa kuota. Sehingga tidak ada alasan sinyal atau kuota. Kemudahan ini diharapkan dapati meningkatkan motivasii belajar siswa selam PJJ.

Latar belakang tersebut dirumuskan masalah, bagaimana motivasi dan hasil belajar siswa setelah menggunakan media pembelajaran berbasis android? 
Media pembelajaran berbasis android untuk meningkatkan motivasi dan hasil belajar siswa

Tujuan Penelitian ini adalah untuk mengetahui dampak dari penggunaan media tersebut terhadap motivasi belajar siswa dan hasil belajar siswa.

Belajari merupakan sebuah proses perubahan tingkah laku dari seseorang. Pengalaman belajar dari seseorang dapat merubah tingkah laku seseorang dari tidak tahu menjadi tahu. (I Mubarak: 2020). Pada teori belajar behavioristik dijelaskan behavioristic merupakan pembelajaran terfokus pada perilaku yang dapat dicermati secara objektif, pada behavioristic belajar adalah hasil perilaku belajar yang berbasis pada lingkungan (I. Lenjani, 2015). Prinsip teori behavioristic adalah perubahan tingkah laku dikarenakan adanya stimulus dan respon serta faktor penguatan. Teori behavioristic menitik beratkan pada input yang berupa rangsangan dan keluaran yang berupa output yang berupa respons. Sedangkan apa yang terjadi antara stimulus dan respon dianggap tidak penting diperhatikan, karena tidak dapat diukur (Rachmawati, T dan Daryanto, 2015, hlm.55).

Berdasarkan beberapa teori tersebut, maka penelitian ini menitik beratkan pada teori behavioristic yang menyatakan bahwa tingkah laku dari peserta didik dapat berubahi kearah yang lebihi baik dikarenakan adanya rangsangan, respon, serta faktor penguatan, intinya bahwa rangsangan pada saat PBM dapat menghasilkan respon yang baik bagi peserta didik.

Rangsangan pada penelitian ini berupa pemberian materi pembelajaran melalui sebuah media yang dapat digunakan oleh siswa dimanapun dan kapanpun, yaitu sebuah media pembelajaran berbasis android. Sedangkan respon atau luaran dari hasil pemberian input tersebut adalah respon dari siswa berupa hasil belajar yang mereka peroleh setelah menggunakan media ini.

Motivasi berasal dari kata "motif" yang berarti daya upaya yang mendorong seseorang untuk melakukan sesuatu. Motivasi merupakan suatu kondisi kesiapsiagaan dalam mencapai suatu tujuan (Sardiman, 1986, hlm. 73). Motivasi adalah perubahan energi dalam diri seseorang yang ditandai dengan munculnya "feeling" dan ditandai dengan tanggapan terhadap adanya tujuan Mc. Donald (dalam Sardiman, 1986, hlm.73). Dalam kegiatan belajar mengajar, apabilai ada seorang peserta didik, tidak1 mengerjakan apa yang harus dia kerjakan dalam pembelajaran hal tersebut dikarenakan suatu sebab-akibat.

Sebab akibat itu biasanya bermacam-macam. Hal ini berarti pada diri peserta didik tidak terjadi perubahan energi, tidak terangsang untuk melakukan sesuatu seperti belajar dan tidak tanggap terhadap tujuan belajarnya. Tidak memiliki motivasi untuk mencapai tujuan belajar akan berakibat pada hasil belajar. Maka pencapaian suatu pembelajaran dan motivasij dapat dilihat dengan hasil belajar peserta didik.

Motivasia peserta didik dapat dilihat dari beberapa hal, antara lain (Sudjana, 2002, hlm. 61):

1) Minat dan perhatian siswa terhadap pelajaran.

2) Semangat siswa untuk melakukan tugastugas belajarnya.

3) Tanggungjawab siswa dalam mengerjakan tugas-tugas belajarnya.

4) Reaksi yang ditunjukkan siswa terhadap stimulus yang diberikan guru.

5) Rasa senang dan puas dalam mengerjakan tugas yang diberikan.

Hasil belajar (learning outcomes) merupakan istilah teknologi pendidikan untuk menyatakan kinerja siswa yang dapat diukur oleh instruktur atau guru (G Terry Page, dkk, 1978: 252), dapat diartikan juga sebagai perwujudan dari peserta didik yang menandakan penguasaan materi tertentu yang dipelajarinya. Selain itu 
Media pembelajaran berbasis android untuk meningkatkan motivasi dan hasil belajar siswa

juga dapat diartikan sebagai pola perbuatan, nilai, sikap, apresiasi, kemampuan serta keterampilan yang tidak sederhana dan dapat berubah sesuai dengan penerimaan dan kebutuhan peserta didik itu sendiri. Definisi singkatnya bahwa hasil belajar merupakan perubahan yang berkesinambungan pada aspek pengetahuan, keterampilan serta sikap sebagai akibat keterlibatan seseorang pada kegiatan belajar (Kyndt, E., 2016).

Hasil merupakan perwujudan dari sebuah penghargaan untuk hal yang telah dipelajari, oleh karena itu dia tidak bersifat menetap, artinya dia dapat berubah sesuai dengan usaha yang dilakukan, namun dapat dipertahankan dengan kesadaran akan pentingnya hasil belajar tersebut (Nurtanto, M., 2016). Penghargaan tersebut dapat berupa pola perbuatan, nilai, ipengertian, sikap, 1apresiasi, abilitas, dani keterampilanh (William Burton dalam (Hamalik, 2013, hlm. 31-32)).

Pada penelitian ini hasil belajar adalah nilai yang diperoleh oleh peserta didik dari tes yang diberikan kepada mereka setelah mereka mendapatkan materi yang disampaikan oleh peneliti secara tatap muka daring (melalui media zoom meeting), kemudian penyampaian materi diperkuat dengan pemberian materi melalui materi berbasis aplikasi android.

Media pembelajaran berasal dari dua kata, media dan pembelajaran. Kata media berasal dari bahasa Latin, yakni medius. Medius secara harfiah berarti tengah, perantara, atau pengantar. Menurut Flemming (dalam Azhar Arsyad 2011, hlm. 3) mengemukakan bahwa "Media sering juga disebut dengan mediatori yaitu penyebab atau alat yang ikut campur tangan dalam dua pihak dan mendamaikannya". Menurut Azhar Arsyad (2011, hlm. 3) mengemukakan bahwa "Kata media berasal dari bahasa latin medius yang secara harfiah berarti tengah, perantara atau pengantar”. Menurut Gerlach \& Ely (dalam Azhar Arsyad 2011, hlm. 3) "Media apabila dipahami secara garis besar adalah manusia, materi, atau kejadian yang membangun kondisi yang membuat siswa mampu memperoleh pengetahuan, keterampilan, atau sikap”.

Menurut Cecep Kustandi dan Bambang Sutjipto (2011, hlm. 7) mengemukakan bahwa "Media memilik pengertian berbagai macam alat yang dapat digunakan untuk menangkap, memproses, dan menyusun kembali informasi ke dalam bentuk visual atau verbal". Menurut Usman (dalam Rasyid 2016, hlm. 70), beliau menyatakan bahwa Media merupakan sesuatu yang bersifat menyalurkan pesan dan dapat merangsang pikiran, perasaan dan kemauan siswa sehingga dapat mendorong terajadinya proses belajar pada dirinya. Penggunaan media secara kreatif akan memungkinkan siswa untuk belajar lebih baik dan dapat meningkatkan performa mereka sesuai dengan tujuan yang ingin dicapai.

Media juga didefinisikan oleh Arief S. Sadiman (2011, hlm. 7) sebagai "Segala bentuk benda yang digunakan oleh guru atau pemateri atau penyalur pesan kepada siswa dan atau penerima materi dan atau penerima pesan untuk menyalurkan informasi atau pesan ssehingga tujuan dari penyaluran pesan atau informasi tercapai”. Media Pembelajaran adalah peralatan yang bertujuan untuk membantu proses belajar mengajar, yang berfungsi untuk memperjelas makna, informasi dan pesan yang disampaikan, sehingga tercapai pembelajaran yang baik, efektifik dan sempurna. Media pembelajaran yakni sarana dan fasiltas kegiatan proses belajar mengajar, dalam memilih media pembelajaran seorang guru juga harus memperhatikan pemilihan yang cocok dan pas, sehingga dapat digunakan secaral maksimal (Cecep Kustandi (2011, hlm 8).

Dari beberapa pemaparan, dapat disimpulkan media pembelajaran adalah suatu fasilitas berupa alat yang digunakan sebagai sarana penopang dalam proses belajar mengajar oleh pengajar dan peserta didik sehingga dapat tercapainya pembelajaran yang baik, efektif. 


\section{METODE}

Penelitian ini menggunakan Pre-Experiment Design, penelitian hanya menguji satu kelompok saja. Desain penelitian one group pretest-posttest design ini diukur dengan menggunakan tes yang diberikan sebelum perlakuan (pretest) kemudian diberikan treatment dan tes yang diberikan setelah perlakuan (posttest). Gambaran rancangan penelitian sebagai berikut.

Tabel 1. Desain Penelitian One Group PretestPosttest

\begin{tabular}{ccc}
\hline Pretest & Perlakuan & Posttest \\
\hline $\mathrm{O} 1$ & $\mathrm{X}$ & $\mathrm{O} 2$ \\
\hline
\end{tabular}

Keterangan:

O1 : Tes awal (Pretest) yang dilakukan sebelum perlakuan.

$\mathrm{X} \quad$ : Perlakuan/treatment

O2 : Tes akhir (Posttest) yang dilakukan setelah perlakuan.

Penelitian ini dilakukan dengan tujuan menerapkan penggunaan media pembelajaran berbasis android serta dampaknya pada siswa kelas XI MIPA 7 SMAN 15 Bandung terhadap motivasi dan hasil belajar siswa. Populasi adalah seluruh objek pada penelitian yang merupakan generalisasi dari sebuah objek atau subjek yang memiliki kualitas dan karakteristik sama yang ditetapkan oleh peneliti (Arikunto, 2012:173) (Sugiyono:2015). Padal penelitian ini yang menjadi populasi adalah siswa kelas XI MIPA 7.

Terdapat dua jenis intrumen, yaitu instrument tes (pretest dan postest) dan instrumen non tes (angket, wawancara, observasi, dan dokumentasi). Pengambilan data pada penelitian ini menggunakan instrumen tes objektif yang disediakan alternatif jawabannya. Selain tes, peneliti juga mencoba memberikan instrumen non tes berupa angket motivasi belajar guna melihat apakah media yang digunakan pada penelitian ini dapat memberikan dorongan kepada siswa kelas XI MIPA 7 SMAN 15 Bandung.
Instrumen non tes sebagai tambahan penelitian ini juga dilakukan validasi oleh ahli materi, selain itu instrument penelitian ini dinilai sudah baku, karena diambil dari angket yang sudah pernah dilakukan uji validasi sebelumnya. Perolehan angket motivasi belajar tersebut kemudian dibandingkan dengan skala presentase motivasi sebagai berikut.

Tabel 2. Skala Prosentase Motivasi

\begin{tabular}{cl}
\hline $\begin{array}{c}\text { Presentase } \\
\text { Pencapaian (\%) }\end{array}$ & \multicolumn{1}{c}{ Interpretasi } \\
\hline$X \geq 76$ & Sangat Termotivasi \\
\hline $56 \leq X<76$ & Termotivasi \\
\hline $40 \leq X<56$ & Cukup Motivasi \\
\hline$X<40$ & Kurang Motivasi \\
\hline & (Arikunto, 2012, hlm. 244)
\end{tabular}

Uji1 normalitas merupakan pengujian data yang sangat diperlukan untuk mengetahui data sampel yang digunakan memenuhi asumsi berdistribusi normal atau tidak (Heryanto, N., dkk, 2013: 8.17), jika hasil dari uji normalitas data tersebut menunjukkan hasil yang normal, maka artinya data sampel dapat dilakukan ke uji perhitungan statistik, karena statistik hitung (parametrik tes) diturunkan dari fungsi distribusi normal.

Terdapat beberapa uji normalitas data, antara lain adalah uji Liliefors, uji KolmogrovSmirnov, uji Anderson-Darling, dan uji Shapiro-Wilks (Heryanto, N., dkk, 2013: 8.17). pengujian kenormalan data pada penelitian ini menggunakan Kolmogrov-Smirnov dengan menggunakan bantuan aplikasi SPSS 20.

Pengambilan keputusan mengenai uji normalitas ini diambil dengan memperhatikan kriteria bahwa data berdistribusi normal jika nilai Absolute Extreme (D) pada tabel hasil Uji Normalitas lebih dari 0,05 (D>0,05), bisa juga menggunakan nilai $\mathrm{Z}$ dengan kriteria data berdistribusil normal jikai $Z>0,05$.

Selain itu dapat diartikan bahwa jika nilai signifikansi pada tabel tersebut di atas 0,05 (Sig > 0,05) Data Normal, sedangakan 
sebaliknya jika signifikansinya kurangi dari 0,05 (Sig<0,05) Data Tidak Normal (I. Zahira : 2017).

Selain uji kenormalan data, diperlukan juga uji homogenitas yang berfungsi untuk melihat proporsi sampel memiliki variasi jawaban yang sama (Wallpole, RE. \& Myers, RH., 1995: 392). Peneliti menggunakan bantuan aplikasi SPSS 20 untuk menguji homogenitas dengan kriteria Homogen jika inilai signifikansi lebih dari 0,05 (sig>0,05) dan tidak homogen jika nilai signifikansi di bawah 0,05 (sig<0,05) (I. Zahira : 2017).

Jika hasil perhitungan normalitas dan homogenitas terhadap data yang diteliti, yaitu hasil pretest dan posttest siswa berdistribusi normal dan homogen, maka perhitungan selanjutnya dapat dilakukans uji statistik, yaitu uji-t (uji signifikansi).

Uji $\mathrm{T}$ atau biasa disebut uji signifikansi berfungsij untuk melihat lapakah perolehan nilai pada variabel tertentu memiliki perbedaan atau perubahan yang signifikan karena dipengaruhi oleh hal lain atau tritmen yang diberikan, dengan kata lain bahwa perubahan nilai atau angka dipengaruhi oleh hal tertentu. Pada kasus disini, peneliti menguji signifikansi dengan uji $\mathrm{T}$ untuk melihat apakah terjadi perubahan nilai pretest ldan nilai posttest yang disebabkan oleh pemberian perlakuan tertentu yaitu pemberian materi melalui media berbasis android.

Kriteria pada uji T menggunakan aplikasi SPSS 20 ini yaitu data dikatakan memiliki perubahan yang signifikan jika perolehan nilai Sig pada hasil perhitungan Paired Samples Test memiliki nilai di bawah 0,05 (sig<0,05), sebaliknya, jika perolehan nya di atas 0,05 (sig>0,05) makal data dikatakan tidak berpengaruh secara signifikan.

\section{HASIL DAN PEMBAHASAN}

Instrumen ini diberikan sebelum pembelajaran atau sebelum media diberikan kepada siswa, maksud dari pemberian pretest ini adalah untuk mengetahui kemampuan awal sebelum diberikannya perlakuan. Kemampuan awal tersebut dapat dilihat pada Tabel 3.

Tabel 3. Hasil Pretest dan Posttest Siswa

\begin{tabular}{|c|c|c|}
\hline No & Pretest & Posttest \\
\hline 1 & 66 & 72 \\
\hline 2 & 61 & 79 \\
\hline 3 & 69 & 65 \\
\hline 4 & 39 & 72 \\
\hline 5 & 43 & 79 \\
\hline 6 & 76 & 79 \\
\hline 7 & 77 & 66 \\
\hline 8 & 62 & 86 \\
\hline 9 & 52 & 72 \\
\hline 10 & 67 & 66 \\
\hline 11 & 13 & 72 \\
\hline 12 & 57 & 86 \\
\hline 13 & 75 & 66 \\
\hline 14 & 67 & 65 \\
\hline 15 & 48 & 52 \\
\hline 16 & 38 & 86 \\
\hline 17 & 58 & 79 \\
\hline 18 & 44 & 79 \\
\hline 19 & 55 & 80 \\
\hline 20 & 59 & 86 \\
\hline 21 & 69 & 86 \\
\hline 22 & 68 & 80 \\
\hline 23 & 64 & 86 \\
\hline 24 & 61 & 73 \\
\hline 25 & 46 & 65 \\
\hline 26 & 60 & 86 \\
\hline 27 & 50 & 59 \\
\hline 28 & 62 & 72 \\
\hline 29 & 74 & 79 \\
\hline 30 & 41 & 53 \\
\hline 31 & 53 & 72 \\
\hline 32 & 67 & 86 \\
\hline 33 & 72 & 86 \\
\hline 34 & 65 & 72 \\
\hline 35 & 47 & 65 \\
\hline 36 & 42 & 79 \\
\hline
\end{tabular}

Instrumen berikutnya yang diberikan kepada siswa adalah instrumen non tes, berupa angket motivasi belajar setelah diberikannya media, berikut hasil dari motivasi belajar siswa. 
Tabel 4. Skor Angket Motivasi

\begin{tabular}{|c|c|}
\hline SISWA & SKOR \\
\hline 1 & 34 \\
\hline 2 & 35 \\
\hline 3 & 36 \\
\hline 4 & 25 \\
\hline 5 & 34 \\
\hline 6 & 32 \\
\hline 7 & 33 \\
\hline 8 & 32 \\
\hline 9 & 35 \\
\hline 10 & 21 \\
\hline 11 & 23 \\
\hline 12 & 34 \\
\hline 13 & 29 \\
\hline 14 & 24 \\
\hline 15 & 39 \\
\hline 16 & 10 \\
\hline 17 & 35 \\
\hline 18 & 20 \\
\hline 19 & 22 \\
\hline 20 & 39 \\
\hline 21 & 10 \\
\hline 22 & 28 \\
\hline 23 & 27 \\
\hline 24 & 26 \\
\hline 25 & 25 \\
\hline 26 & 26 \\
\hline 27 & 10 \\
\hline 28 & 33 \\
\hline 29 & 30 \\
\hline 30 & 32 \\
\hline 31 & 31 \\
\hline 32 & 22 \\
\hline 33 & 24 \\
\hline 34 & 27 \\
\hline 35 & 28 \\
\hline 36 & 30 \\
\hline Rata-rata & 27,80556 \\
\hline
\end{tabular}

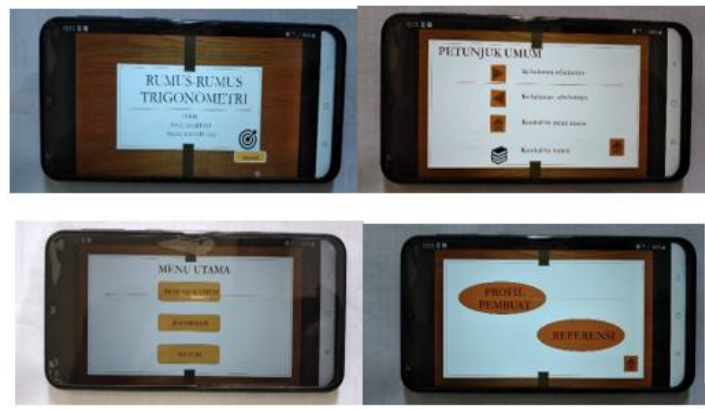

Gambar 1. Media Pembelajaran Berbasis Android

Dari angket yang diberikan, yang terdiri dari sebelas pernyataan, yakni delapan pernyataaan positif dan empat pernyataan negatif. Jika dilihat hasil rekapan untuk dampat termotivasi atau tidaknya, maka dapat dibuatkan dalam diagram lingkaran sebagai berikut.

\section{Hasil Angket}

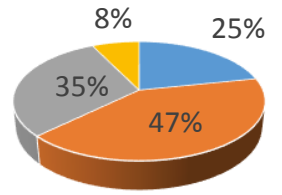

- Sangat Termotivasi - Termotivasi

- Cukup Termotivasi - Kurang Termotivasi

Gambar 2. Diagram Hasil Angket Motivasi

Terdapat 25\% siswa yang sangat termotivasi, 47\% termotivasi, 35 cukup termotivasi, dan hanya $8 \%$ yang kurang termotivasi. Kita dilihat dari angkanya, jumlah yang termotivasi jauh lebih banyak dibandingkan dengan jumlah yang kurang termotivasi. Jika kita gabungkan kategori sangat termotivasi dan termotivasi, maka sebanyak $72 \%$ dari siswa termotivasi untuk belajar lebih baik lagi dengan adanya media pembelajaran berbasis android ini.

Uji normalitas dilakukan untuk mengetahui apakah sebaran data berdistribusi normal atau tidak. Hal ini dilakukan untuk mengetahui 
Media pembelajaran berbasis android untuk meningkatkan motivasi dan hasil belajar siswa

langkah yang akan dilakukan dalam pengujian hipotesis. Jika sebaran data berdistribusi normal, maka pengolahan data yang dilakukan selanjutnya dapat dilakukan dengans metode parametrik. Jika sebaran data tidak berdistribusi normal, maka dapat dilakukan pengolahan data secara non parametrik.

Untuk mengetahui apakah sebaran data berdistribusil normal atau tidak, dilakukan pengujian dengan hipotesis sebagai berikut.

Ho : sampel berasal dari populasi yang berdistribusi normal

H1 : sampel tidak berasal dari populasi yang berdistribusi normal

Pengambilan kesimpulan dilakukan dengan ketentuan:

"Jika nilai signifikansi $>\alpha$, maka Ho diterima dan H1, kondisi lain Ho ditolak" Pada pengujian data instrumen tes, dilakukan uji normalitas terlebih dahulu untuk mengetahui apakah data berdistribusi normal atau tidak.

Dari tabel 4.2 dapat dilihat nilai signifikansinya 0.726. Jika diambil $\alpha=0.05$, maka pada pengujian ini Ho diterima karena $0.726>0.05$. Sehingga dapat disimpulkan bahwa populasi memiliki sebaran data yang berdistribusi normal, berarti peningkatan hasil bealajar siswa kelas XI MIPA 7 berdistribusi normal. Karenai data memiliki sebaran data berdistribusi normal, maka selanjutnya data dapat diolah dengan metode statistik parametrik. Pengujian selanjutnya yang dilakukan adalah uji homogenitas.

Uji homogenitas dilakukan untuk mengetahui apakah variansi nilai pretest dan posttest homogens atau tidak. Langkah ini dilakukan untuk mengetahui pengujian selanjutnya akan dilakukan. Jika varians data kedua kelas sampel homogen, maka pengolahan data dilanjutkan dengan uji perbedaan dua rerata dengan uji t. Sedangkan jika varians data pretest dan posttest tidak homogen, maka pengolahan data dilanjutkan dengan uji perbedaan dua rata-rata dengan uji t.

Berikut hipotesis untuk uji homogenitas.

Ho : $\sigma_{1}{ }^{2}=\sigma_{1}{ }^{2}$ (tidak terdapat perbedaan antara nilai pretest dan posttest)

H1 : $\sigma_{1}{ }^{2} \neq \sigma_{2}{ }^{2}$ (terdapat perbedaan nilai pretest dan posttest)

Berdasarkan tabel 4.3, nilai signifikansinya diperoleh 0.092. Jika diambil $\alpha=0.05$, maka pada pengujian ini Ho diterima dan H1 ditolak, karena $0.092>0.05$. Hal ini, berarti varians data kedua kelompok homogen, sehingga dapat disimpulkan bahwa data pretest dan posttest homogen.

Uji signifikansi merupakan uji terakhir pada penelitian ini, uji ini dimaksudkan untuk melihat apakah terjadi peningkatan hasil belajar yang signifikan berdasarkan perolehan nilai Pretest dan Posttest yang diakibatkan oleh pemberian perlakuan, pada penelitian ini treatment yang diberikan oleh peneliti kepada responden yaitu memberikan media belajar berbasis android.

Kriteria pada uji signifikansi data dikatakan memiliki perubahan yang signifikan jika perolehan nilai Sig pada hasil perhitungan Paired Samples Test memiliki nilai di bawah 0,05 ( sig<0,05), sebaliknya, jika perolehan nya di atas 0,05 (sig >0,05) maka data dikatakan tidak berpengaruh secara signifikan.

Hasil yang diperoleh pada penelitian ini adalah nilai signifikansi $=0,000$, ini berarti nilai tersebut <0,05, maka dapat dikatakan bahwa, terdapat perbedaan yang signifikan antara lnilai Pretest dan Posttest yang disebabkan oleh adanya perlakukan pemberian media pembelajaran berbasis android.

Berdasarkan hasil ini dapat disimpulkan bahwa media pembelajaran berbasis android yang dibuat oleh peneliti dapat meningkatkan hasil 
Media pembelajaran berbasis android untuk meningkatkan motivasi dan hasil belajar siswa

belajar siswa kelas XI MIPA 7 SMAN 15 Bandung.

\section{KESIMPULAN}

Berdasarkan hasil penelitian, setelah dilakukan perlakukan, pengambilan data, dan pengolahan data, maka dapat disimpulkan, penggunaan media pembelajaran berbasis android ini berdasarkan hasil skor motivasi yang diperoleh, rata-rata siswa memperoleh skor motivasi yang tinggi. Penggunaan media berbasis android ini, dari hasil pengolahan skor/nilai pretest dan posttest dengan menggunakan uji $\mathrm{T}$, menunjukkan terdapat peningkatan hasil belajar yang signifikan.

\section{REFERENSI}

Arief S. Sadiman. (2011). Media Pendidikan. Jakarta: Rajawali Pers.

Arikunto, Suharsimi. (2012). Prosedur Penelitian. Jakarta: Rineka Cipta.

Arsyad, Azhar. (2011). Media Pembelajaran. Jakarta: PT. Raja Grafindo Persada

Cecep Kustandi dan Bambang Sutjipto. (2011). Media Pembelajaran Manual dan Digital. Bogor: Ghalia Indonesia.

Edi Ismanto, dkk. (2017). Pemanfaatan Smartphone Android Sebagai Media Pembelajaran Bagi Guru SMA Negeri 2 Kota Pekanbaru. JURNAL Untuk Mu negeRI VOL. 1, NO.1, MEI 2017. ISSN : 2550-0198 . 42

G Terry Page, dkk. (1978). International Dictionary of Education. New York: Kogan Page/Nichols Publishing.

Hamalik, Oemar. (2013). Proses Belajar Mengajar. Jakarta: PT.Bumi Aksara

Heryanto, N., dkk. (2013). Statistika Pendidikan. Universitas Terbuka: Tangerang Selatan.

Kyndt, E. (2016). Teachers' Everyday Professional Development: Mapping Informal Learning Activities, Antecedents, and Learning Outcomes. Review of Educational Research. Month 201X, Vol. $\mathrm{XX}$, No. X, pp. 1-40. DOI: 10.3102/0034654315627864. (C) 2016 AERA. http://rer.aera.net

Lenjani. (2015). Constructivism And behaviorism Methodologies On Special Needs Education. European Journal Of Special Education Research. Volume 1| Issue $1 \mid$ September 2015. Available online at: www.oapub.org/edu

Liliawati Jeni. (2017). Analisis Pemanfaatan Sumber Belajar Dalam Proses Pembelajaran. Seminar Nasional Tahunan Fakultas Ilmu Sosial Universitas Negeri Medan Tahun 2017, 17 May 2017. http://semnasfis.unimed.ac.id/wpcontent/uploads $/ 2$

M. Nurtanto. (2016). Peningkatan Motivasi Dan Prestasi Belajar Dengan Metode Problem Based Learning Pada Pembelajaran Gambar Teknik Melalui Pembelajaran Terbimbing. VANOS-Journal Of Mechanical Engineering Education. Vol.1, No.2, Desember 2016, Hlm.201-216. ISSN 25282611, e-ISSN 2528-2700. http://jurnal.untirta.ac.id/index.php/vanos

Rachmawati, T \& Daryanto. (2015). Teori Belajar Dan Proses Pembelajaran Yang Mendidik. Yogyakarta: Gava Media

Sardiman, A.M. (1986). Interaksi dan Motivasi Belajar-Mengajar. Jakarta: PT Raja Grafindo Persada

Setiawan, Risky, dkk. (2019). Efektivitas blended learning dalam inovasi pendidikan era industri 4.0 pada mata kuliah teori tes klasik. Jurnal Inovasi Penidikan. Vol 6, No 2.

https://doi.org/10.21831/jitp.v6i2.27259

Sona Rahmada Yani, dkk. (2020). Analisis Penggunaan Media Sosial Dan Sumber Belajar Digital Dalam Pembelajaran Bagi Siswa Digital Native Di SMAN 2 Painan. . Jurnal Pendidikan ekonomi. Vol.13. No.1 Maret
2020. 
https://dx.doi.org/10.17977/umo14v13i120 20poo1 .

Sugiyono. (2015). Metode Penelitian dan Pengembangan, Penerbit Alfabeta Bandung. Yogyakarta.

Undang-undang No. 20 Tahun 2003 Bab II Pasal 3. Republik Indonesia

Wallpole, RE. \& Myers, RH., (1995). Ilmu Peluang dan Statistika untuk Insyinyur dan Ilmuwan. Bandung: ITB. 